\title{
INSTITUTIONAL CRITERIA FOR THE ASSESSMENT OF INTELLECTUAL PRODUCTS` POTENTIAL REALIZATION IN THE VENTURE FINANCING SYSTEM
}

The objective of the research is to elaborate institutional criteria for the assessment of intellectual products 'potential realization in the venture financing system which are not presented in the existing works on venture investments.

Research methodology is based on synthesis of institutional and new institutional economics theory, theories of innovations, uncertainty and risk, management of innovations.

Essential characteristics of venture financing are structured in the paper, its treatment as an economic category is suggested. A number of common institutional criteria for the assessment of intellectual products ` potential feasibility in the system of venture financing are outlined and grounded.

The structure of institutional field of venture financing (by the example of Sverdlovsk region) is elaborated with consideration of projected development and coevolution of formal and informal institutions as a favorable environment for drawing into economic turnover and commercialization of technological developments and projects.

Analytical investigation of structural elements for creation of institutional field of venture financing in Sverdlovsk region is performed, a range of common and specific problems, contradictions and recommendations are outlined.

The paper introduces institutional criteria for the assessment of intellectual products' potential feasibility.

Keywords: venture financing, intellectual products ` potential, institutional assessment criteria, institutional field

Building a national venture financing system is an objective necessity for Russia determined by specific features of innovation economy establishment in developed countries and the pressing demand for securing "sustainable, extended and bal-

\footnotetext{
${ }^{1}$ This research has been fulfilled with financial support of the Russian Humanitarian Science Foundation grant (Project No. 11-32-00218a1 "Modeling of assessment system of intellectual products ' potential in the sphere of science").
}

anced reproduction of the national wealth on an intense basis..." in our country [25, p. 21].

There are several definitions of venture financing of innovative projects and companies. Following general cumulative characteristics of venture financing may be outlined:

Venture capital is a funding source for start-up companies, newly-established companies or companies under complex conditions. Venture investments carry a high risk of failure, but at the same 
time they offer good prospects of income - above the average [28, p. 145].

Venture capital is a specific resource which constitutes a unity of financial and human capital and therefore has the synergistic effect on business activity in economical systems through development of innovative and investment activity [30, p. 34].

According to some authors, venture capital as a funding source encourages business growth by means of provision of a fixed sum of money in exchange for share in charter capital or some equity stake [10, p. 8].

Venture capital is regarded also as a kind of share capital provided by professional firms which invest with simultaneous management into private firms showing significant potential at the stages of start-up, expansion and transformations [2, p. 8].

In the venture capital study course elaborated by EVCA and RVCA, venture capital is regarded as a sort of direct investments into equity capital at the stages of start-up, early growth or expansion of business [17].

Analysis of the European venture capital financing experience showed that in these countries there are almost no differences between the notions of venture capital and direct investments and both terms are often used as synonyms. Characteristic features of venture business in the USA are orientation towards investing into innovative firms which realize advanced technologies in different branches of industry, and high rate of early stages firms among the recipients of investments. Therefore, in the USA the term "venture capital" is used for determining investment into companies at the early stages of development and investment into high-tech companies not listed on the stock exchange [17].

In modern conditions, up to $80 \%$ of GDP in developed economies is ensured due to innovations and high technologies, therefore all around the world investment into innovative developments including those financed by venture capital is one of the most profitable ways of capital placement.

In this connection, major theoretical and methodological background of our research are essential characteristics of such social and economic category as "intellectual resource" suggested by A. I. Tatarkin, which reflect methodology of reproductional approach required for studying complex intellectual objects and processes [25].

J. Schumpeter's theory of innovations should be mentioned without doubt as one of the theoretical backgrounds of venture financing. One of the most important conclusions of this theory is that the only way to receive fixed return and possibly excess profit for the leading entrepreneur is using continuous innovations which assume endogenous and permanent character in the system of innovative entrepreneurship [33].

Findings of representatives of institutional economic theory and new institutional economics, which use contract theory, transaction cost theory and economic theory of property rights in capacity of theoretical and methodological background, are justifiably considered systematically important for investigation of economic relationships at all stages of innovation process [6].

However, while analyzing aforementioned theories and theoretical orientations as basic by formation of institutional theory of venture financing, one should, in our opinion, use them in conjunction with the theories of finance, risk, innovation management, marketing etc. Such methodology of research is determined by contemporary realities of the venture capital financing process, integrated into complex system of relationships of bringing technologies to marketable state, their transfer, commercialization, as well as establishment of new companies and firms.

Within the framework of innovation management theory, special prominence should be given to theoretical and practical relevance of Henry Chesbrough's "open innovation" concept [32]. Venture capital business executives participate in the innovation process in an open innovation community in cooperation with researchers, managers, marketing consultants, consumers, partners and competitors.

Distinguishing feature of venture entrepreneurship from other types of business activity with inherent risk is higher grade of entrepreneurial risk and special methods of sharing risk between such participants of venture financing process as investor and entrepreneur. For example, in comparison with investment into free traded shares venture investments show less sound liquidity, greater extent of information asymmetry and higher investment risks.

Analysis of national and foreign experience of venture investment shows that specific features of venture capital are financing of developments and projects with higher risk grade. In the first place, the indicated features appear in the aims and character of funds application in the innovation process. In the second place, there is high risk to lose 
contributed capital for a variety of reasons: unpredictability of creative process' result, without which no innovation could occur; possible mistake in the idea forming the basis of innovation project; difficulties of technical implementation of the project; unpredictable market reaction to a newly-designed product etc. [3]

This high level of risk in the venture financing sphere is determined, first of all, by essential features of intellectual products in the sphere of science and technology stipulating unpredictability of economic return and receiving an income, complexity of rights differentiation when creating intellectual products as well as high level of uncertainty by realization and utilization of these products. Among these features, we emphasize the following ones:

- Limitation of objectification and embodiment;

- Possible intangible character; level;

- High technological, scientific and technical

- Unpredictability and unobviousness of scientific discoveries and inventions;

- Quite high level of uncertainty, non-linearity of cost, terms and results of scientific research and development;

— "Non-appropriatability", "inalienability", unexpendability in consumption etc. [4, pp. 152-221].

We determine and analyze intellectual product as a complex and comprehensive product, as potential and real intellectual property items. Potential of intellectual products of scientific and technological sphere is interpreted and revealed in our research as realized and unrealized capacities and opportunities of accumulation and productive utilization of intellectual products for satisfaction of needs of the state, scientific community, education, business and other stakeholders [4, pp. 24-225].

Furthermore, it is reasonable to consider the following provisions:

1. Complexity of commercialization and realization of intellectual products ' potential consists in their genesis, specific features of creative endeavor, formation and realization of researchers ' creative potential [7];

2. Realization of intellectual products' potential is determined by diverse range of relationships, contradictions and rights of parties involved into creation, elaboration, assessment and commercialization of intellectual products [5];

3. A considerable number of theoretical, methodological and practical problems in the process of drawing these products into economic turnover oc- cur in connection with the diversity of their embodiment and performance, their metamorphoses. In many cases, these products combine all or separate features of varieties of their embodiment: in tangible physical form, form of various rights and powers, services or know-how. Creation and commercialization of these products involves a broad range of conditions on macro-, meso- and microlevel [8].

Realization of intellectual products' potential under appropriate circumstances may yield high return but, at the same time, is connected with high risks.

Perception and realization of the marked and analyzed theoretical and methodological developments is, in our opinion, the basic valuation criterion of intellectual products ' potential realization in the sphere of science and technology. Scientifically grounded utilization of these developments encourages the most complete implementation of intellectual products ' potential in the process of drawing these products into economic turnover, commercialization, including in the form of high-technology products in-demand in the world market.

Introduction of new products (services) into the market, ambition to become the leader in the chosen sphere, earning an excess profit distinguish innovative function of venture entrepreneurship as a basis of a "new economy" [29]. Subject to further development of venture capital financing the most rapid growth of knowledge-intensive and high-technology sectors can be achieved.

In the light of specific features characteristic of Russian economy, venture financing as an economic category reflects, in our opinion, the system of social and economic relationships between the concerned agents regarding realization of intellectual products' potential, lowering of the uncertainty and risk level, investment of funds into bringing these products to marketable state, development of innovative enterprise and mutually beneficial distribution of profits from realization of innovative products.

High level of uncertainty is especially indicative for venture capital financing at early stages of scientific and technological projects. Substantial level of uncertainty is connected also with absence of proper risk investment legislation system in Russia, including protection of venture investor's rights. For instance, in the USA fundamentals of legislation determining investor's rights and obligations have not changed for more than 40 years. Game rules are known to all participants of the venture business, there are guarantees that these rules won't change 
Venture investments in Russia by project stage, 2007-2010 [21]

\begin{tabular}{|l|c|c|c|c|c|c|c|c|}
\hline \multirow{2}{*}{ Stages } & \multicolumn{2}{|c|}{2007} & \multicolumn{2}{c|}{$\mathbf{2 0 0 8}$} & \multicolumn{2}{c|}{$\mathbf{2 0 0 9}$} & \multicolumn{2}{c|}{$\mathbf{2 0 1 0}$} \\
\cline { 2 - 9 } & $\begin{array}{c}\text { Investments } \\
\text { volume, USD mln }\end{array}$ & $\mathbf{\%}$ & $\begin{array}{c}\text { Investments } \\
\text { volume, USD mln }\end{array}$ & $\%$ & $\begin{array}{c}\text { Investments } \\
\text { volume, USD mln }\end{array}$ & \% & $\begin{array}{c}\text { Investments } \\
\text { volume, USD mln }\end{array}$ & \% \\
\hline Seed and start-up & 42,12 & 4,10 & 67,81 & 4,61 & 13,29 & 2,60 & 19,51 & 0,80 \\
\hline Early & 66,18 & 6,50 & 93,95 & 6,38 & 110,46 & 21,7 & 131,78 & 5,30 \\
\hline Expansion & 909,23 & 89,4 & 1310,65 & 89,01 & 314,15 & 61,9 & 2240,89 & 89,8 \\
\hline Restructuring & 0 & 0 & 0 & 0 & 70,00 & 13,8 & 2,66 & 0,10 \\
\hline Mature stages & 0 & 0 & 0 & 0 & 0 & 0 & 100,00 & 4,00 \\
\hline Total & 1017,53 & 100 & 1472,41 & 100 & 507,9 & 100 & 2494,84 & 100 \\
\hline
\end{tabular}

in the process of project implementation, besides, there are guarantees of keeping these rules by all parties.

Venture business practice demonstrates that market is not a self-regulating thing-in-itself. State plays a significant role in the establishment of venture funds. Thus, in the USA state impact on development of venture financing is evidenced in the proactive policy of support of small innovative business (which includes in particular the Small Business Innovation Development Act dated 1982, prescribing to the governmental authorities whose research and development cost make up not less than USD 100 million a year to reserve $1,25 \%$ of their research budget for provision subsidies and contracts to small firms; policy of the research and development centers' incentives stimulating elaboration of up-to-the-minute technology by small firms etc.) [3].

According to the investigations in the area of institutional theory and practice of venture financing, various national venture systems have their own specific institutional character in realization and accommodation of economic interests in the innovation activity sphere, sources of financing, specific national venture entrepreneurship models. Development of venture financing in industrialized countries is built with consideration of institutional features of capital markets performance, innovations, securities, including national traditions and characteristic aspects of scientific and technological policy, national path of precedent development etc. In contrast to Russia, in these countries assessment criteria of intellectual products' potential realization are used with consideration of specific national features.

During the starting phase of transition to market economy, a venture financing institution in Russia was established by way of importation of separate elements of institutional venture business structure from developed countries. However, according to the statistical data and real practice, simple borrowing of ready infrastructure elements was not enough for appearance of a fully valid venture investments sector in our country and for implementation of available prospective innovation projects. Thus, taking into account the innovation projects pipeline available within the country, in fact only a few of them are implemented. Hence, for example, a share of high-technology products in the total volume of export from Russia in 2010 amounted to 9\% (As a comparison, this figure in the USA in 2010 was equal to $20 \%$, in Japan - 18\%) [24].

Especially significant for the Russian economy is support of scientific and technological projects at initial stages since, according to the RVCA data presented in table 1, the share of seed and startup stages investments is decreasing steadily and amounted in 2010 to only $0,8 \%$ of the total volume of venture investments [21]. As a comparison, in the USA seed stage investments made up $7 \%$ of the total venture investments amount in 2010 and 3\% for 9 months of 2011 [34].

Venture support of projects at initial stages is essential because in Russia there is a break in the chain of "fundamental research — applied research - engineering developments - production" which prevents from securing effective transfer of scientific insights in the R\&D sphere and bringing scientific and technological products to commercial use. Furthermore, fundamental science is financed insufficiently and the financing volume is inclined to reduce further [9, pp. 10-18].

Arrangement of conditions for financial support of scientific and technological projects at initial stages is another principal institutional criterion for the assessment of realization of intellectual products` potential.

Import of market institutions from developed countries, including venture capital financing in- 
stitution, is inevitably connected with high transaction expenses. Reduction of this cost within the venture investments sector is possible subject to further development in Russia of market economy and free competition intrinsic to it. Development of venture financing requires also effective legal and economic environment, change of informal elements of institutional structure, e. g. development of business relations standards, overcoming of institutional traps in Russian economy (such as shadow economy, corruption, administrative burden, non-payments etc.).

In Russia mentality of native venture capitalists is characterized by tendency to invest into mature stages of innovation project when the risks are significantly lower acts as an institutional constraint or barrier for performance of venture financing. Aiming to minimize risks, venture investors are focused on investing large amounts (above USD 500000), giving priority to companies already acknowledged in the market. Attracting of small (from 10 to 50 thousand dollars) and average amounts (from 50 to 500 thousand dollars) for young innovative companies which have not yet a track record is a problem of great concern [1].

At the present time, foreign capital funds prevail in the structure of venture funds operating in Russia. Among big investors Baring Vostok, Delta Private Equity Partners, Eagle Venture Partners, EBRD and Berkeley Capital Partners can be named. Russian venture capital is presented, first of all, by JSC "Russian Venture Company" [18]. Institution of business angels which are traditionally occupying a niche of initial investments into prospective scientific and technological projects in the whole world is only starting to form in Russia.

At the current stage common understanding appears in our country that while elaborating scope of government regulation measures is directed at creation of new institutions, institutional factors of economy development should be considered which means that it is necessary to change both formal and informal norms.

As shown in table 1, overall across Russia after economic crisis of the end 2008th financing volume of innovation sphere significantly reduced

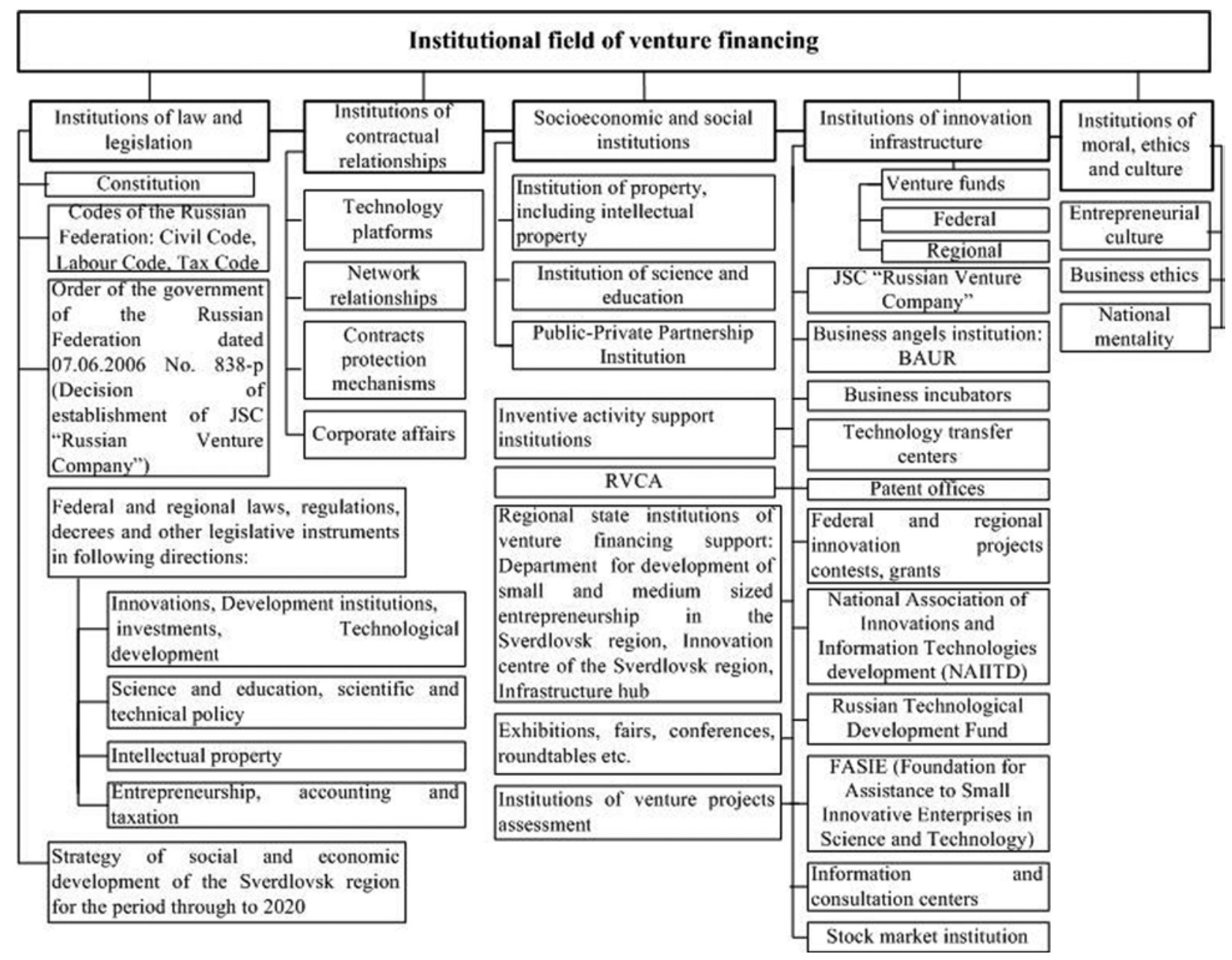

Fig. Institutional field of the venture financing system (by the example of Sverdlovsk region) 
in 2009 and amounted to 507, 9 million dollars in comparison to 1472 million dollars in 2008. In 2010 recovery of venture investments market took place and investment volume reached 2495 million dollars. For reference, venture investments volume in the USA in 2010 amounted to 23263 million dollars which exceeds the level of Russia by more than 9 times [34].

Efforts of entrepreneurs, business and government to create a competitive national model of venture entrepreneurship in Russia are not systemic and purposeful. Among the reasons are insufficient depth and integrity of theoretical and methodological developments reflecting specific institutional features of various national venture capital generation and utilization mechanisms, lack of a clear state innovation and investment strategy, insufficient elaboration of a technology transfer and intellectual property legal framework, specific risks for venture investments and focus of Russian entrepreneurs on short-term investments. In connection with this, one of the most crucial tasks in the current period is creation of an institutionally flexible and integral system of venture entrepreneurship.

Along with this, in the draft of a such base document as "Framework paper of Russian Federation policy on development of science and technology for the period through to 2020 " [20] the role of venture financing as an effective means of commercialization of scientific and technological developments and project was not emphasized among the contributory factors for achievement of a strategic goal of state scientific and technology policy in the Russian Federation. However, this document outlines achievement of a global level of research and developments in the directions determined by national scientific and technological priorities and development of the sixth technology revolution in Russia to 2020. The "Framework..." provides for improvement of a venture financing institution for support of starting innovative companies within the task of innovation processes activation in economy and social sphere and stimulation of internal consumer demand for innovations. Besides, venture innovation funds are mentioned as a component of innovation activity infrastructure system.

From our point of view, creation, development and interconnection of key institutions (institutional field) of venture financing is a principal institutional criterion for the assessment of realization of intellectual products potential in the system of venture financing. High grade of development of these in- stitutions facilitates transformation of intellectual products` potential into high-yield innovative enterprises, firms etc.

We structured key institutions, on the basis of which an institutional field of venture financing can be formed (by the example of Sverdlovsk region) (figure).

Overall in Russia and in Sverdlovsk region in particular there is a shortage of financial conditions for stimulation of innovation activity, high technologies and human capital, development of a fullscaled venture financing institution.

One of the principal criteria for the assessment of realization of intellectual products ' potential in the scientific and technological sphere is every possible development of civilized treaty, contractual and networking relations (on the pattern of developed countries) between the agents of the venture financing system regarding development of intellectual products, risk sharing, drawing these products into economic turnover and their implementation into marketable products and assets.

The "Framework paper of Russian Federation policy on development of science and technology for the period through to 2020" stipulates for development of a "federal contract system of the Russian Federation in so far as it relates to research, development and technological work, by way of arrangement of the state requirements for research and development and transfer of technologies, created with the use of budget funds, to the real economy with observance of intellectual property rights" [20, p. 39], as well as "accreditation within the federal purchasing system of legal entities which perform research and development for the purpose of participation in government research, development and technological activity" [20, p, 39].

Development of this system is especially significant for realization of intellectual products ' potential in the sphere of science and technology.

It should be noted that at the present time government of our region takes steps towards innovative development of economy and entrepreneurship including field of high technologies. Implementation of measures to stimulate the development of small business and innovative entrepreneurship is focused on achievement of the goals established in the Strategy of social and economic development of Sverdlovsk region for the period through to 2020 .

In 2010 a special vehicle was established in Sverdlovsk region to render full range of services required by entrepreneurs at all stages of a company 
development - an Infrastructure hub and innovation centre for small and medium-sized business $[13,15]$.

New instruments of entrepreneurship support have been elaborated including support of venture entrepreneurship, among which grants for creation of new innovation enterprises in amount of up to RUR 500000, reimbursement of expenses of existing innovative companies; export-oriented companies support program including reimbursement of expenses connected with products certification, payment of interest on loans and purchase of equipment can be mentioned; reimbursement of the first rate under leasing agreements; youth entrepreneurship development program; energy efficiency rising program for small and medium-sized business entities etc. [14].

Various events on innovations are held in the course of the Infrastructure hub activity including Small business forum "START-UP", own program of the Infrastructure hub within "Innoprom", Forum "Start your business", Forum of production cooperation, Youth innovation forum, conferences, round tables and strategic sessions. Regional infrastructure and projects of small and medium-sized enterprises of the region are presented within the "Rosnanoforum", "Innovations and investments salon", "International congress of innovative companies", "World small business exhibition" and other major Russian and international events [15, 31].

Perspective is development of venture industry using elements of public-private partnership and creation in Sverdlovsk region of specialized sector-specific venture funds which exist in western countries. These funds are formed out of the funds of large enterprises. Sector-specific venture funds invest into projects of a particular industry sector. Professional experts can carry out a more qualitative selection of prospective projects in specific branches which can reduce the projects duration $[12,16]$.

On the whole it can be noted that at the present time local and federal authorities realize a set of measures on development of the venture financing institution of projects and insights in the sphere of science and technology. However, the venture investments market in Sverdlovsk region as well as in Russia is at the forming stage and there is a lack of both funding sources and qualitatively prepared projects. Along with this, venture financing as a development institution represents a condition and a factor of modernization and self-development of the regions economy within the system of other leading institutions [26, 27].

Elements of an innovative "ecosystem" in Sverdlovsk region are operating disconnectedly from each other, that is significantly narrowing down opportunities for innovative development of the regional economy. The reporting system which should inform investors about opportunities of profitable investments into prospective innovation projects in the region`s territory is not balanced yet $[11,23]$.

It is worth mentioning that the created elements of the institutional field of venture financing are not able to show the expected results: for example, the Closed Share Investment Fund "Regional Venture Fund of investments into small enterprises of the scientific and technological sphere of Sverdlovsk region" established in December 2007 under management of CJSC "Asset Management Company "Yermak" has financed only 3 projects for 3 years [22], and in 2010 Sverdlovsk region sent a federal budget grant application for establishment of a Foundation for Assistance to Investments into small and medium-sized business entities in Sverdlovsk region by way of reorganization of the Foundation for Assistance to venture investments into small enterprises in the sphere of science and technology of Sverdlovsk region $[11,19]$.

As a result of the undertaken study a conclusion can be made that formation of institutional criteria for the assessment of intellectual products ' potential realization in the scientific and technological sphere within the venture financing system is a complex task. It is connected with both specific features of intellectual products ' potential and dynamics of development in a broad context of institutional field for this type of financing.

We detailed following principal institutional criteria determining assessment of intellectual products ' potential feasibility in the venture financing system:

1. Perception and realization of the system of theoretical and methodological developments is, in our opinion, the basic valuation criterion of intellectual products ' potential realization in the sphere of science and technology. Scientifically grounded utilization of these developments encourages the most complete implementation of intellectual products potential in the process of drawing these products into economic turnover, commercialization, including in the form of high-technology products in-demand in the world market. 
2. Arrangement of conditions for financial support of scientific and technological projects at initial stages is another principal institutional criterion for the assessment of realization of intellectual products` potential.

3. From our point of view, creation, development and interconnection of key institutions (institutional field) of venture financing is a systemic institutional criterion for the assessment of intellectual products' potential feasibility.

4. One of the principal criteria for the assessment of realization of intellectual products' potential is every possible development of civilized treaty, contractual and networking relations (on the pattern of developed countries) between the agents of the venture financing system regarding development of intellectual products, risk sharing, drawing these products into economic turnover, their implementation into marketable products and assets.

Build-up of the venture financing system with consideration of fundamental criteria detailed above and other will encourage development of innovation economy, receiving profits from realization of intellectual products' potential in the sphere of science and technology, increase of science-intensive products`share in the GDP.

\section{References}

1. Alekhina N. M. (2009). Venture financing as an innovative development. Innovations, 6, 49-52.

2. Balaban A. M., Balaban M. A. (1999). Venture financing of innovation projects. Moscow, ANE.

3. Venture financing: foreign experience (analytical articles). Available at: http://www.solev.ru/ (Accessed 19 March 2012).

4. Volkova T. I. (2004). Reproduction of creative potential of science. Yekaterinburg, Institute of Economics, the Ural Branch of Russian Academy of Sciences.

5. Volkova T. I. (2006). Commercialization of intellectual products in the sphere of science: institutional analysis. Economy of Region, 3, 98-111.

6. Volkova T.I. (2008). The market of intellectual products: theoretical background for analysis. The Journal of Economic Theory, 4, 12-28.

7. Volkova T.I. (2006). Creative potential of science as object for theoretical economic research. Bulletin of the Ural State University of Economics, 2, 3-12.

8. Volkova T. I. (2009). Endogenous factors of commercialization of intellectual products in scientific and technological sphere. Innovations, 11, 51-56.

9. Volkova T. I., Usoltsev I. A. (2010). Intellectual products in the sphere of science: potential of commercialization. Yekaterinburg, Institute of Economics, the Ural Branch of Russian Academy of Sciences.

10. Gulkin P. (2002). Venture capital. List of terms. Corporate management. Available at: http://www.ofin.ru/investor/ventureglossary (Accessed 13 January 2012).

11. Innovation portal of the Ural Federal district. Available at: http://www.invur.ru/ (Accessed 13 January 2012).

12. Innovations and business: weblog (2009). Available at: http://www.fointec.ru/ (Accessed 13 January 2012).

13. Innovation centrefor smalland medium-sized business ofSverdlovskregion. Availableat:http://www.инновационныйцентр. pф (Accessed 13 January 2012).

14. Information bulletin of Chamber of Commerce and Industry of the Russian Federation on small business issues (February 2011). Available at: http://www.smb.gov.ru/ (Accessed 13 January 2012).

15. Infrastructure hub of small and medium enterprise of the Sverdlovsk region. Available at: http://www.infrahub.ru/ (Accessed 13 January 2012).

16. Results of the first Ural venture forum. Regional department of the All-Russian public organization "Delovaya Rossiya". Available at:http://www.deloros-ural.ru/ (Accessed 13 January 2012).

17. Venture entrepreneurship training course EVCA-RVCA. Available at: http://allventure.ru/ (Accessed 13 January 2012).

18. JSC "Russian Venture Company". Available at: http://www.rusventure.ru/ (Accessed 13 January 2012).

19. Operating statement on small and medium-sized business development in Sverdlovsk region (18 May 2010 - 18 May 2011). Available at: http://www.otchet2011.ru/sozdannaya_infrastruktura_podderzhki/investicionnye_fondy/ (Accessed 13 January 2012).

20. "Framework paper of Russian Federation policy on development of science and technology for the period through to 2020" (2011). Innovations, 9, 37-41.

21. Direct and venture investments in Russia - 2010. Preliminary market review. Electronic library of the internet portal "Venture Russia". Available at: http://www.allventure.ru/ (Accessed 13 January 2012).

22. Regional Venture Fund of investments into small enterprises of the scientific and technological sphere of Sverdlovsk region. Available at: http://www.ural-venture.ru/ (Accessed 13 January 2012).

23. Sverdlovsk regional business-incubator. Available at: http://sobi-ural.ru/ (Accessed 13 January 2012).

24. Statistical data of the Worldbank. Available at: http://data.worldbank.org/indicator/TX.VAL.TECH.MF.ZS (Accessed 13 January 2012).

25. Tatarkin A. I. Intellectual capital of the society and its function in the reproduction process (2010). Economy of Region, 3 , $32-42$.

26. Tatarkin A. I., Doroshenko S. V. (2011). Region as a self-developing socio-economic system: crossing the crisis. Economy of Region, 1, 15-23. 
27. Tatarkin A.I., Tatarkin D. A. Innovative mission of the social system modernization as a need for sustainable development of Russia. Economy of Region, 2, 25-37.

28. Dictionary of venture capital financing terms (2004). Saint-Petersburg.

29. Federal portal of small and medium sized entrepreneurship. Available at: http://smb.gov.ru/ (Accessed 20 January 2012).

30. Folomyov A. N., Noibert M. (1999). Venture capital. Saint-Petersburg, Science.

31. Foundation for Assistance to Small Innovative Enterprises in Science and Technology. Available at: http://www.fasie.ru/ (Accessed 13 January 2012).

32. Chesbrough Henry (2007). Open Innovation. Translation from English. Moscow, Pokoleniye.

33. Schumpeter J. (1982). The Theory of Economic Development. Moscow, Progress.

34. Pricewaterhouse Coopers / National Venture Capital Association Money Tree ${ }^{\mathrm{Ts}}$ Report. Thomson Reuters (2011). Available at: http://www.thomsonreuters.com/, http://www.pwcmoneytree.com/ (Accessed 13 January 2012).

\section{Information about authors}

Volkova Tatiana Ivanovna (Yekaterinburg, Russia) - Doctor of Economics, Professor, Head of the Sector for institutional economics, Institute of Economics, Ural Branch of the Russian Academy of Sciences (620014, Yekaterinburg, Moskovskaya st. 29, e-mail: randall@bk.ru).

Kuznetsova Marina Nikolaevna (Yekaterinburg, Russia) - PhD student, Institute of Economics, Ural Branch of the Russian Academy of Sciences (620014, Yekaterinburg, Moskovskaya st. 29, e-mail: vinarskaya-m@yandex.ru). 